\title{
ANALISIS KETERAMPILAN DASAR VISUAL GEOMETRI SISWA SMP DITINJAU BERDASARKAN LEVEL BERPIKIR ANALISIS VAN HIELE
}

\author{
Dewi Yuliana ${ }^{1}$, Novisita Ratu ${ }^{2}$ \\ 1,2,3 Pendidikan Matematika, FKIP, Universitas Kristen Satya Wacana, Salatiga \\ 202016028@student.uksw.edu
}

\begin{abstract}
Abstrak
This research is a descriptive qualitative research which aims to describe the basic visual geometry skills of students on the subject matter quadrilateral. Sampling subjects are using a purposive sampling technique that consisting of 3 students of class VIII A Salatiga State Junior High School 3 2019/2020 ie students who have been doing VHGT test and the results have a level of thinking van Hiele analysis. Data collection technique that consisting test methods, interviews and documentation through 4 steps of analysis, namely data collection, data reduction, data presentation and conclusion drawing. The results of this study indicate that the three students who have analytical thinking level are able to achieve each of the basic visual geometric skills indicators on quadrilateral, but the three students had difficulty in determining the basis of grouping in question number 3 , which means that the same students have van Hiele analysis thinking level will have similarities in solving problems.
\end{abstract}

Keywords: Geometry Visual Skills, Quadrilateral, Van Hiele

\begin{abstract}
Abstrak
Penelitian ini merupakan penelitian kualitatif desktiptif yang bertujuan untuk mendeskripsikan keterampilan dasar visual geometri siswa pada materi pokok segiempat. Pengambilan sampel subjek menggunakan teknik purposive sampling yang terdiri dari 3 siswa kelas VIII A SMP Negeri 3 Salatiga tahun ajaran 2019/2020 yaitu siswa yang telah mengerjakan tes VHGT dan hasilnya memiliki level berpikir analisis van Hiele. Teknik pengumpulan data dengan metode tes, wawancara dan dokumentasi dengan melalui 4 langkah analisis yaitu pengumpulan data, reduksi data, penyajian data dan penarikan kesimpulan. Hasil penelitian ini menunjukkan ketiga siswa yang memiliki level berpikir analisis mampu mencapai setiap indikator keterampilan dasar visual geometri pada materi segiempat, akan tetapi ketiga siswa kesulitan dalam menentukan dasar pengelompokkan pada soal nomor 3 artinya siswa yang sama memiliki level berpikir analisis van Hiele akan memiliki kesamaan dalam menyelesaikan soal.
\end{abstract}

Kata Kunci : Keterampilan Visual Geometri, Segiempat, Van Hiele

Tujuan kurikulum 2013 (Permendikbud No 24 Thn 2016) terdapat empat kompetensi yang dicapai dalam proses pembelajaran salah satunya adalah kompetensi keterampilan. Permasalahan dalam menyelesaikan soal, skill (keterampilan) merupakan metode yang dimiliki oleh siswa untuk proses belajar dan memperoleh hasil belajar yang bermakna dalam pembelajaran matematika . Keterampilan sendiri tidak diukur dari berapa umur siswa tersebut melainkan dilihat dari cara siswa tersebut dapat menalar, memahami dan menyelesaikan soal (Risnawati 2013). Menurut Hoffer (1981) keterampilan dasar geometri yang dimiliki siswa untuk memahami konsep geometri seperti Visual (K1), Verbal (K2), Menggambar (K3), Logika (K4), Terapan (K5). Keterampilan visual meliputi mengenal variasi bangun datar atau ruang, mengamati bagian-bagian dari sebuah bangun dan keterkaitan bagian satu dengan bagian yang lain, menunjukkan sumbu simetri, dan mengklasifikasikan bangun-bangun geometri menurut ciri-ciri teramati, menyimpulkan informasi lanjut berdasarkan pengamatan visual, dan memvisualisasikan model geometri (Sofyana 2011). 
Analisis Keterampilan Dasar Visual Geometri Siswa SMP Ditinjau Berdasarkan Level Berpikir Analisis Van Hiele, Dewi

Berdasarkan silabus pembelajaran SMP / MTs 2017, matematika memiliki ruang lingkup mencakup materi: bilangan, aljabar, geometri dan pengukuran, dan statistika dan peluang. Geometri sendiri merupakan salah satu cabang matematika yang mempelajari ukuran, bentuk, dan posisi bentuk bangun 2 dimensi dan 3 dimensi. Geometri memiliki peluang lebih besar dari ruang lingkup yang lain untuk dipahami oleh siswa, karena geometri cocok untuk pengalaman langsung dan cara yang efektif untuk menjangkau siswa dalam mengalami kesulitan di dalam kelas. Geometri dapat dilihat secara nyata dikehidupan sehari-hari dalam bentuk benda sekitar misalnya : pintu rumah, jendela, ubin, buku, jam dinding dan lainnya.

Pada kenyataanya geometri yang begitu nyata dalam kehidupan sehari-hari masih sulit dipahami oleh siswa, hal ini menyebabkan konsep geometri siswa masih tergolong rendah. Hal ini juga diperkuat dengan adanya hasil yang diperoleh dari Daya Serap UN SMP / MTs tahun 2017 /2018 dalam presentase Nasional, dapat dilihat pada Tabel 1 berikut.

\section{Tabel 1}

Presentase Siswa Yang Menjawab Benar Tahun Pelajaran 2017 / 2018

\begin{tabular}{|c|l|c|}
\hline No & \multicolumn{1}{|c|}{ Materi Yang Diuji } & Nasional \\
\hline 1 & Bilangan & 44,99 \\
\hline 2 & Aljabar & 41,88 \\
\hline 3 & Geometri dan Pengukuran & 41,40 \\
\hline 4 & Statistika dan Peluang & 45,71 \\
\hline
\end{tabular}

Sumber : https://hasilun.puspendik.kemdikbud.go.id

Persentase dari tabel diatas dapat dilihat untuk keempat materi yang diujikan ternyata materi geometri dan pengukuran memiliki presentase yang paling rendah. Pada materi geometri dan pengukuran yang diujikan presentase siswa mampu menjawab benar sebesar 41,40\% . Dari hasil diatas dapat disimpulkan bahwa pembelajaran geometri tingkat kesukaranyya cukup tinggi, sehingga siswa kesulitan untuk menyelesaikan soal.

Menyelesaikan masalah geometri juga membutuhkan proses berpikir dalam menerapkan konsep dan keterampilan yang digunakan untuk menyelesaikan masalah tersebut. Abdussakir (2010) menyatakan dalam teori Van Hiele siswa akan melalui lima tahap, dimana lima tahap itu mengajak siswa untuk secara berurutan berpikir ke level yang lebih tinggi. Pendapat Van De Walle setiap tingkatan atau tahap pemikiran geometri van hiele memiliki level, dimana setiap level tersebut menggambarkan pemikiran siswa. Pada kelas tinggi (kelas 6 -8) sebagian besar siswa tersebut berada pada level visualisai, analasis dan level deduksi informal (Walle 2013).

Penelitian tentang level geometri di sekolah sudah banyak dilakukan seperti yang diungkapkan Aditya (2016) teori Van Hiele yang didasarkan pada kemampuan geometri dan gender siswa SMP kelas 7 disimpulkan bahwa setiap siswa memiliki karakteristik cara berpikir yang tidak sama. Siswa laki-laki dan perempuan berkemampuan tinggi berada pada tahap level 2 (level 2 belum sempurna). Siswa lakilaki memiliki kemampuan visual lebih baik dari perempuan, tetapi siswa perempuan lebih baik dalam kemampuan verbalnya. Sedangkan siswa berkemampuan rendah berada pada level 1 analisis. 
Penelitian lain yang diungkapkan Silfi Zainatu dkk (2017) mengungkapkan bahwa siswa mengalami kesulitan mengenai sifat-sifat bangun datar yang diberikan. Hal ini terjadi karena kurangnya pemahaman konsep siswa terkait sifat - sifat bangun datar yang hanya sekedar dihafal tanpa melihat visual bentuk bangun yang diberikan. Sehingga perlu adanya penanaman tentang pemahaman konsep dan keterampilan dasar geometri yang dimiliki siswa untuk dapat digunakan dalam menyelesaikan soal geometri. Selain itu Holifatul (2015), melakukan penelitian keterampilan yang mengungkapkan untuk keterampilan yang dimiliki siswa berkemampuan tinggi adalah keterampilan visual, verbal dan menggambar dari 3 keterampilan yang diujikan. Keterampilan yang dimiliki siswa berkemampuan sedang dan rendah hanya keterampilan visual dari 3 keterampilan yang diujikan. Berdasarkan latar belakang penelitian ini, maka tujuan penelitian ini adalah untuk mendiskripsikan dan mengetahui sejauh mana keterampilan visual geometri yang dimiliki siswa ditinjau berdasarkan level berpikir analisis Van Hiele.

\section{METODE}

Jenis penelitian adalah penelitian deskriptif kualitatif. Subjek penelitian ini 3 siswa kelas VIII A yang bersifat heterogen di SMP N 3 Salatiga semester ganjil tahun ajaran 2019/2020. Subjek dipilih menggunakan teknik purposive sampling, yaitu peneliti memilih subjek dengan pertimbangan tertentu. Pertimbangan tersebut antara lain: (1) telah mengerjakan tes pertama (VHGT) dan memiliki level berpikir van Hiele tertinggi dikelas (2) rekomendasi dari guru pengampu matematika, (3) subjek mampu dan mau untuk mengerjakan soal tes dan wawancara, dan (4) memiliki kemampuan komunikasi yang baik.

Teknik pengumpulan data dengan metode tes, wawancara dan dokumentasi. Hasil tes akan dianalisis sesuai indikator keterampilan dasar visual geometri siswa pada materi segiempat. Wawancara dilakukan semi terstruktur dimana pertanyaan yang diajukan dapat dikembangkan tetapi tidak keluar dari topik pembahasan. Instrumen utama penelitian ini adalah peneliti itu sendiri, sedangkan instrumen bantu yang digunakan adalah soal tes Van Hiele Geometry Test (VHGT), tes keterampilan visual materi segiempat, pedoman wawancara, dan alat rekam. Soal tes (VHGT) terdiri dari 25 soal pilihan ganda yang terbagi menjadi 5 subtes, soal tes keterampilan visual pada materi segiempat terdiri dari 4 soal uraian yang telah divalidasi oleh ahli dosen Pendidikan Matematika Universitas Kristen Satya Wacana Salatiga dan salah satu guru matematika SMP Negeri 3 Salatiga. Indikator keterampilan visual yang digunakan dalam penelitian ini diadaptasi dari Hoffer yang dapat dilihat pada Tabel 2 berikut.

\section{Tabel 2}

Kisi-Kisi Tes Keterampilan Dasar Visual

\begin{tabular}{|c|l|l|}
\hline $\begin{array}{c}\text { Keterampilan } \\
\text { Dasar }\end{array}$ & \multicolumn{1}{|c|}{ Aspek } & \multicolumn{1}{|c|}{ Indikator Butir Soal } \\
\hline $\begin{array}{c}\text { Keterampilan } \\
\text { Visual }\end{array}$ & $\begin{array}{l}\text { Mengenal variasi bentuk } \\
\text { bangun datar. }\end{array}$ & $\begin{array}{l}\text { Diberikan gambar macam-macam bangun datar, siswa } \\
\text { diminta untuk menentukan bangun segiempat dan bukan } \\
\text { segiempat. }\end{array}$ \\
\hline
\end{tabular}




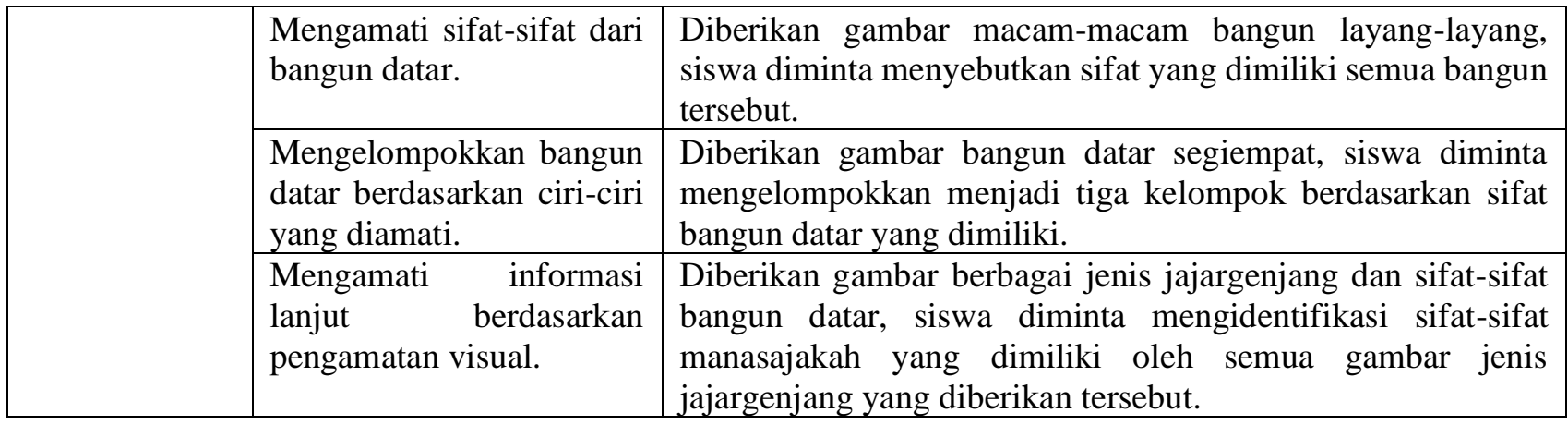

Teknik analisis data dilakukan melalui pengumpulan data, reduksi data, penyajian data yaitu data disajikan dalam bentuk tulisan yang disusun dengan baik dan runtut agar mudah dilihat, dibaca, dan dipahami, penarikan kesimpulan.

\section{HASIL}

Hasil subjek penelitian pada tes pertama (VHGT) dari 31 siswa diperoleh hasil 17 siswa masih berada pada level pravisualisasi, 7 siswa level visualisasi (level 0) dan 7 siswa level analisis (level 1). Pada tes kedua diperoleh 3 subjek dan hasilnya berupa deskripsi keterampilan visual geometri materi segiempat.

\section{Karakteristik Soal No 1}

Soal no 1 dikategorikan sebagai indikator pertama pada aspek keterampilan visual materi pokok segiempat, dimana indikator ini menjadi tahap awal siswa mengenal bangun secara visual. Dalam menjawab soal, subjek harus paham soal dan mampu melihat informasi-informasi secara visual terkait macam-macam dari bentuk bangun datar secara keseluruhan dalam posisi yang berbeda. Setelah mampu melihat informasi-informasi mengenai bangun datar tersebut, subjek dapat mengelompokkan atau membedakan antara bangun segiempat dan bukan segiempat.

\section{Deskripsi Keterampilan Visual Subjek Pada Soal No 1}

\section{Subjek FP}

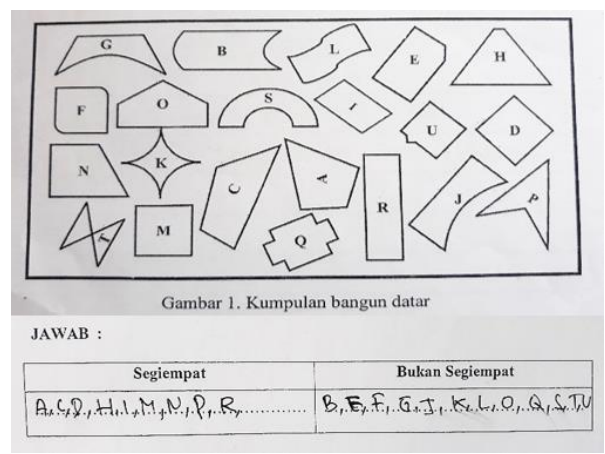

Gambar 1. Jawaban Subjek FP Soal Nomor 1

Berdasarkan hasil jawaban soal tes dan wawancara pada indikator mengenal variasi bentuk bangun datar, subjek FP mampu mengenal bangun datar segiempat dan bukan segiempat berdasarkan 
tampilan keseluruhan dari gambar kumpulan bangun datar yang diberikan. Subjek FP mendeskripsikan segiempat adalah bangun yang memiliki 4 sisi atau ruas garis dan 4 sudut yang apabila dijumlahkan $360^{\circ}$. Setelah melakukan wawancara untuk mengetahui informasi lebih mendalam mengenai kemampuan subjek FP, diperoleh bahwa subjek FP menjawab bangun P adalah segiempat dimana subjek dapat memberi alasan dan menunjukkan terdapat 4 sisi dan 4 sudut. Ketika wawancara subjek FP juga sudah bisa menyebutkan nama dari setiap bangun segiempat dari tampilan secara keseluruhan dengan posisi yang berbeda secara tepat. Kesimpulan dari hasil jawaban soal tes dan wawancara bahwa subjek FP telah paham tentang konsep bentuk bangun datar segiempat secara visual dan mampu mencapai pada indikator mengenal variasi bentuk bangun datar.

\section{Subjek NO}

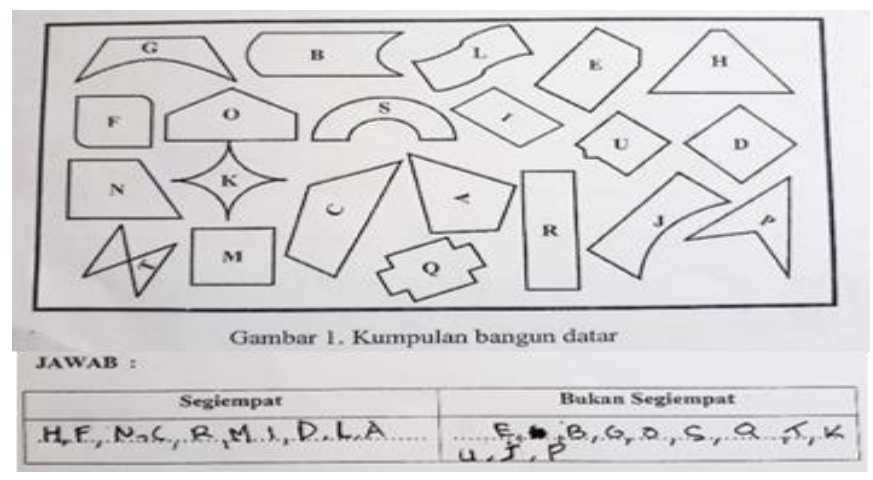

Gambar 2. Jawaban Subjek No Soal Nomor 1

Berdasarkan hasil jawaban soal tes dan wawancara pada indikator mengenal variasi bentuk bangun datar, subjek NO memahami soal nomor 1 akan tetapi belum mampu mengenal bangun datar segiempat dan bukan segiempat berdasarkan tampilan keseluruhan dari gambar kumpulan bangun datar yang diberikan. Subjek NO menyebutkan bangun F, L segiempat dan bangun P bukan segiempat. Subjek NO mendeskripsikan segiempat adalah bangun yang memiliki 4 sisi dan 4 sudut. Pada saat wawancara subjek NO menjawab bangun F dan L segiempat karena memiliki 4 sisi dan 4 sudut ketika disuruh menunjukkan keempat sudutnya subjek NO berubah jawaban bahwa bangun $\mathrm{F}$ hanya memiliki 2 sudut, dan garis samping yang melengkung bukan sudut. Sedangkan bangun L menurut subjek garis yang melengkung juga merupakan sisinya sehingga bangun L juga segiempat. Untuk bangun P subjek NO menjawab bahwa bukan segiempat tetapi ketika wawancara jawaban subjek berubah bahwa bangun $\mathrm{P}$ termasuk segiempat dan dapat memberikan alasannya. Ketika wawancara subjek NO juga sudah bisa menyebutkan nama dari setiap bangun segiempat dari tampilan secara keseluruhan dengan posisi yang berbeda secara tepat. Kesimpulan dari hasil jawaban soal tes dan wawancara bahwa subjek NO kurang paham tentang konsep bentuk bangun datar segiempat secara visual mampu mencapai pada indikator mengenal variasi bentuk bangun datar. 


\section{Subjek CN}

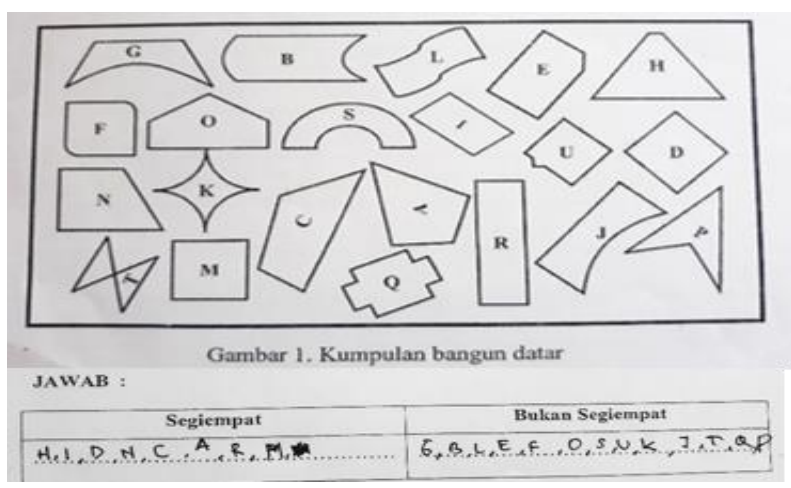

Gambar 3. Jawaban Subjek CN Soal Nomor 1

Berdasarkan hasil jawaban soal tes dan wawancara pada indikator mengenal variasi bentuk bangun datar, subjek $\mathrm{CN}$ mampu memahami soal nomor 1 dan mengenal bangun datar segiempat dan bukan segiempat berdasarkan tampilan keseluruhan dari gambar kumpulan bangun datar yang diberikan. Subjek CN mendeskripsikan segiempat adalah bangun yang memiliki 4 sisi dan 4 sudut. Pada saat wawancara subjek $\mathrm{CN}$ menjawab bangun $\mathrm{P}$ bukan segiempat karena dilihat dari tampilannya subjek $\mathrm{CN}$ menyebutkan bahwa bangun tersebut merupakan segitiga. Ketika disuruh melihat kembali jawaban subjek CN sedikit berubah dengan alasan bangun $\mathrm{P}$ memiliki 4 sisi dan 4 sudut serta dapat menunjukkannya dan mengungkapkan jika bangun P merupakan bangun segiempat. Subjek CN sudah bisa menyebutkan nama dari setiap bangun segiempat dari tampilan secara keseluruhan dengan posisi yang berbeda secara tepat. Kesimpulan dari hasil jawaban soal tes dan wawancara bahwa subjek FP telah paham tentang konsep bentuk bangun datar segiempat secara visual mampu mencapai pada indikator mengenal variasi bentuk bangun datar.

\section{Karakteristik Soal No 2}

Soal no 2 dikategorikan sebagai indikator kedua pada aspek keterampilan visual materi pokok segiempat. Dalam menjawab soal, subjek harus paham soal dan mampu melihat informasi-informasi yang diketahui secara visual terkait macam-macam kumpulan bangun layang-layang dalam posisi yang berbeda. Setelah mampu melihat informasi-informasi mengenai bangun datar yang terdapat pada soal tersebut, subjek dapat menuliskan sifat-sifat yang dimiliki oleh semua kumpulan layang-layang kemudian membandingkan sifat-sifat yang ditulis dengan kumpulan bangun yang tersedia.

\section{Deskripsi Keterampilan Visual Subjek Pada Soal No 2}

\section{Subjek FP}

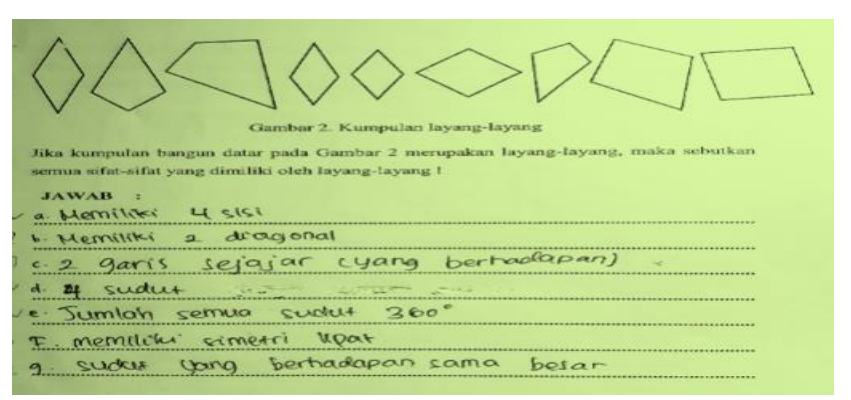

Gambar 4 Jawaban Subjek FP Soal Nomor 2 
Berdasarkan hasil jawaban soal tes dan wawancara pada indikator mengamati sifat-sifat dari bangun datar, subjek FP memahami pertanyaan yang diberikan dimana subjek FP mengungkapkan jika soal yang diberikan disuruh menuliskan sifat dari kumpulan layang-layang. Subjek FP juga mampu menyebutkan bangun datar apa saja yang dilihat dari gambar 2 yaitu bangun datar layang-layang dan belah ketupat dari posisi yang berbeda-beda Subjek FP menuliskan 7 sifat yang dimiliki pada soal nomor 2, dapat dilihat dari jawaban subjek FP menuliskan beberapa sifat yang dimiliki oleh layanglayang hanya melihat dari gambar salah satunya, tetapi tidak melihat dari kedua bangun yang telah disebutkan diawal. Ketika wawancara jawaban subjek FP sedikit berubah, pada sifat c yang menyebutkan 2 garis yang berhadapan sejajar ketika dilihat kembali dengan melihat keseluruhan posisi dua bangun subjek FP menyebutkan jika belah ketupat memiliki 2 sisi yang sejajar tetapi layang-layang tidak memiliki, kemudian subjek FP mengungkapkan jika sifat $\mathrm{c}$ yang ditulis salah. Pada sifat $\mathrm{f}$ dan $\mathrm{g}$ yang telah ditulis subjek FP sudah benar tetapi kurang tepat, dimana subjek FP mengulangi dengan menulis sifat yang dimiliki kumpulan layang-layang tersebut dilihat dari salah satu bangun saja. Pada saat wawancara subjek FP melihat gambar kembali dan mengungkapkan untuk bangun belah ketupat memiliki 2 simetri lipat, 2 sudut yang berhadapan sama besar dan layang-layang memiliki 1 simetri lipat, 1 sudut yang berhadapan sama besar. Selain itu ketika peneliti meminta untuk menujukkan sifatsifat yang kurang spesifik yang telah dituliskan subjek FP mampu menujukkannya dan benar. Untuk sifat yang lainnya subjek FP sudah benar dalam menjawab dan mampu memberikan alasan dan menunjukkan sifat-sifat yang telah ditulis. Kesimpulan hasil jawaban soal tes dan wawancara tersebut subjek FP sudah paham mengenai sifat-sifat yang ditulis dan sesuai dengan sifat yang dilihat dari gambar 2, tetapi kurang spesifik dalam menuliskan sifat-sifat yang telah diketahui dari soal yang dimiliki oleh layang-layang.

\section{Subjek NO}

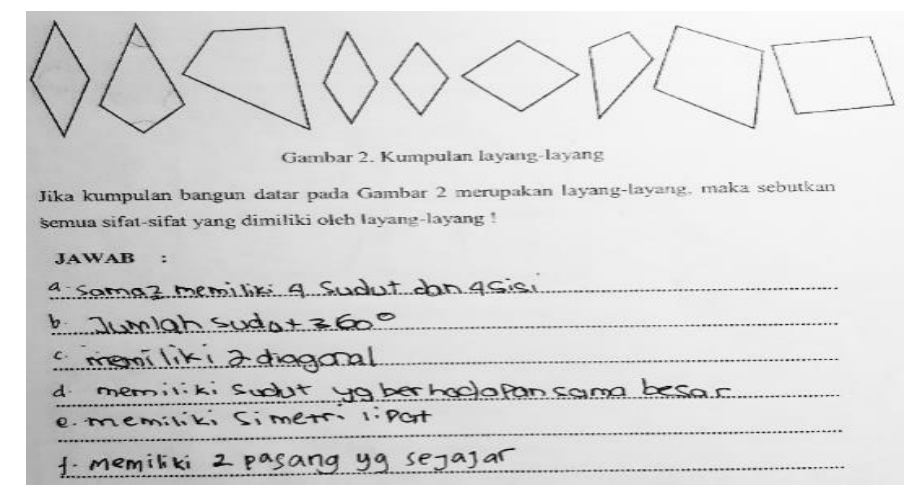

Gambar 5. Jawaban Subjek NO Soal Nomor 2

Berdasarkan hasil jawaban soal tes dan wawancara pada indikator mengamati sifat-sifat dari bangun datar, subjek NO memahami pertanyaan yang diberikan dimana subjek NO mengungkapkan jika soal yang diberikan disuruh menuliskan sifat dari kumpulan layang-layang. Subjek NO juga mampu menyebutkan bangun datar apa saja yang dilihat dari gambar 2 yaitu bangun datar layang-layang dan 
belah ketupat dari posisi yang berbeda-beda. Subjek NO menuliskan 6 sifat yang dimiliki pada soal nomor 2, dapat dilihat dari jawaban subjek menuliskan beberapa sifat yang dimiliki oleh layang-layang hanya melihat dari gambar salah satunya, tetapi tidak melihat dari kedua bangun yang telah disebutkan diawal. Ketika wawancara jawaban subjek NO sedikit berubah, pada sifat $\mathrm{f}$ yang menyebutkan 2 garis yang berhadapan sejajar ketika dilihat kembali dengan melihat keseluruhan posisi dua bangun subjek NO menyebutkan jika belah ketupat memiliki 2 sisi yang sejajar tetapi layang-layang tidak memiliki, kemudian subjek NO mengungkapkan jika sifat $\mathrm{f}$ yang ditulis salah. Pada sifat e dan $\mathrm{d}$ yang telah ditulis subjek NO sudah benar tetapi kurang tepat, dimana subjek NO mengulangi dengan menulis sifat yang dimiliki kumpulan layang-layang tersebut dilihat dari salah satu bangun saja. Pada saat wawancara subjek NO melihat gambar kembali dan mengungkapkan untuk bangun belah ketupat memiliki 2 simetri lipat, 2 sudut yang berhadapan sama besar dan layang-layang memiliki 1 simetri lipat, 1 sudut yang berhadapan sama besar. Selain itu ketika peneliti meminta untuk menujukkan sifat-sifat yang kurang spesifik yang telah dituliskan subjek NO mampu menujukkannya dan benar. Peneliti juga meminta subjek CN untuk menyebutkan apa lagi sifat yang dimiliki sifat dari gambar 2, subjek CN mengungkapkan bahwa sudut berdekatan jumlahnya $180^{\circ}$. Untuk sifat yang lainnya subjek NO sudah benar dalam menjawab dan mampu memberikan alasan dan menunjukkan sifat-sifat yang telah ditulis. Kesimpulan hasil jawaban soal tes dan wawancara tersebut subjek NO sudah paham mengenai sifatsifat yang ditulis dan sesuai dengan sifat yang dilihat dari gambar 2, tetapi kurang spesifik dalam menuliskan sifat-sifat yang telah diketahui dari soal yang dimiliki oleh layang-layang.

\section{Subjek CN}

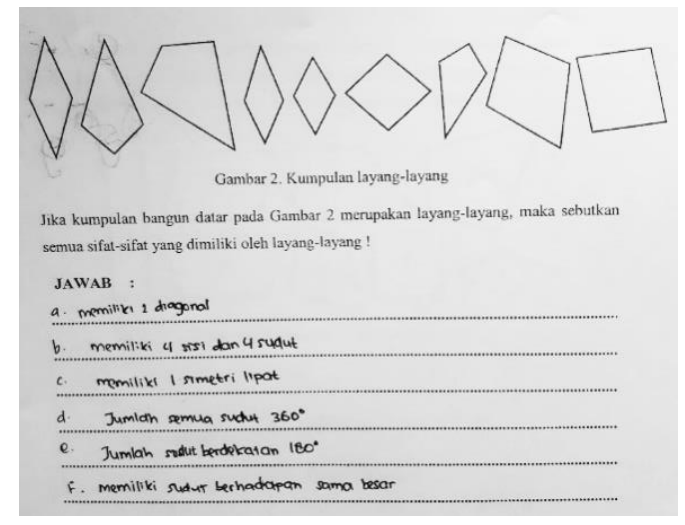

Gambar 6. Jawaban Subjek CN Soal Nomor 2

Berdasarkan hasil jawaban soal tes dan wawancara pada indikator mengamati sifat-sifat dari bangun datar, subjek CN memahami pertanyaan yang diberikan dimana subjek CN mengungkapkan jika soal yang diberikan disuruh menuliskan sifat dari kumpulan layang-layang. Subjek CN juga mampu menyebutkan bangun datar apa saja yang dilihat dari gambar 2 yaitu bangun datar layang-layang dan belah ketupat dari posisi yang berbeda-beda. Subjek CN menuliskan 6 sifat yang dimiliki pada soal nomor 2, dapat dilihat dari jawaban subjek $\mathrm{CN}$ menuliskan beberapa sifat yang dimiliki oleh layang- 
layang hanya melihat dari gambar salah satunya, tetapi tidak melihat dari kedua bangun yang telah disebutkan diawal. Pada sifat $\mathrm{f}$ yang telah ditulis subjek $\mathrm{CN}$ sudah benar tetapi kurang tepat, dimana subjek CN menjawab sifat yang dimiliki kumpulan layang-layang tersebut dilihat dari salah satu bangun saja. Pada saat wawancara subjek $\mathrm{CN}$ melihat gambar kembali dan mengungkapkan untuk bangun belah ketupat memiliki 2 sudut yang berhadapan sama besar dan layang-layang memiliki 1 sudut yang berhadapan sama besar. Ketika ditanya alasan sifat e yang ditulis pada jawaban, subjek CN mampu memberikan alasan dan benar menunjukkan pada gambar. Untuk sifat yang lainnya subjek CN sudah benar dalam menjawab dan mampu memberikan alasan dan menunjukkan sifat-sifat yang telah ditulis. Kesimpulan hasil jawaban soal tes dan wawancara tersebut subjek $\mathrm{CN}$ sudah paham mengenai sifatsifat yang ditulis dan sesuai dengan sifat yang dilihat dari gambar 2, tetapi kurang spesifik dalam menjawab dan menuliskan sifat yang telah diketahui dari soal yang dimiliki oleh layang-layang.

\section{Karakteristik Soal No 3}

Soal no 3 dikategorikan sebagai indikator ketiga pada aspek keterampilan visual materi pokok segiempat. Dalam menjawab soal, subjek harus paham soal dan mampu melihat informasi-informasi yang diketahui secara visual, dapat mencari dasar pengelompokkan menjadi tiga kelompok sesuai gambar 3 kumpulan bangun datar. Setelah mampu melihat informasi-informasi mengenai bangun datar yang terdapat pada soal tersebut, subjek dapat menuliskan jenis pengelompokkan sesuai dengan dasar pengelompokkan yang dipakai.

\section{Deskripsi Keterampilan Visual Subjek Pada Soal No 3}

\section{Subjek FP}

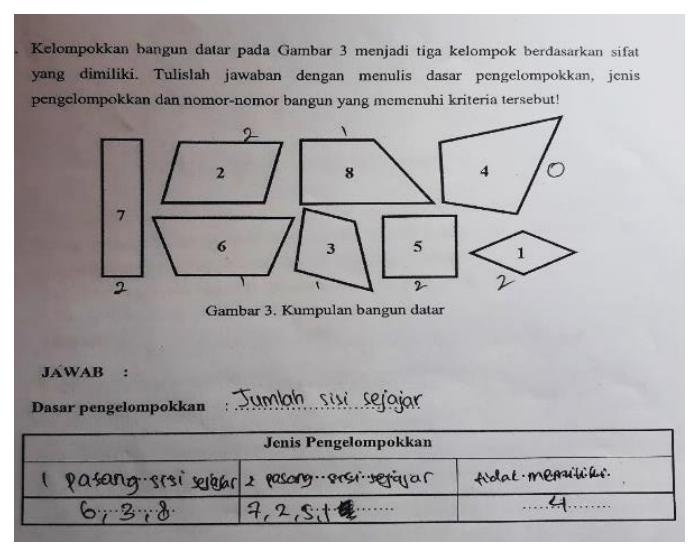

Gambar 7. Jawaban Subjek FP Soal Nomor 1

Berdasarkan hasil jawaban soal tes dan wawancara pada indikator mengelompokkan bangun datar berdasarkan ciri-ciri yang diamati, subjek FP telah memahami soal nomor 3 tetapi awalnya kesulitan ketika menjawab soal nomor 3. Pada saat wawancara subjek FP pertama kali memilih dasar pengelompokkan macam-macam segiempat karena gambar 3 merupakan bangun datar segiempat, tetapi terbagi menjadi 4 kelompok yaitu persegi, jajar genjang, trapesium dan layang-layang. Kedua subjek FP memilih dasar pengelompokkan sisi yang berhadapan sama panjang tetapi juga terbagi melebihi 3 kelompok. Dasar pengelompokkan terakhir adalah banyaknya sisi sejajar, dimana subjek FP 
mengungkapkan bahwa arti sisi sejajar apabila sisi yang berhadapan arahnya sama walaupun panjangnya berbeda. Pada wawancara subjek FP mampu menjelaskan banyaknya sisi sejajar dan menunjukkan sisi mana saja yang sejajar disetiap bangun pada gambar 3 yang dilihat. Kesimpulan dari jawaban soal tes dan wawancara, subjek FP sudah paham secara visual mengenai sifat-sifat yang dimiliki setiap bangun datar segiempat secara keseluruhan dan dapat menjelaskan dengan benar.

\section{Subjek NO}

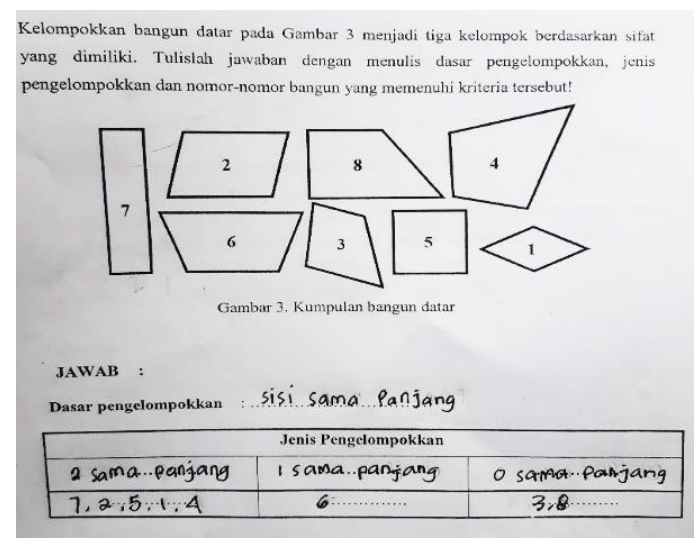

Gambar 8 Jawaban Subjek NO Soal Nomor 3

Berdasarkan hasil jawaban soal tes dan wawancara pada indikator mengelompokkan bangun datar berdasarkan ciri-ciri yang diamati, subjek NO telah memahami soal tetapi merasa kesulitan ketika menjawab soal nomor 3. Pada saat wawancara subjek NO pertama kali langsung memilih dasar pengelompokkan sisi sama panjang, dengan alasan jika dilihat sisi didepannya ada yang sama persis panjangnya. Ketika subjek NO melihat kembali gambar 5 dan 1, jawaban subjek NO berubah melihat bangun 5 bahwa bangun persegi sisinya semuanya sama dan pada bangun 1 belah ketupat jawaban subjek NO tetap sama bahwa sisi yang berhadapan sama panjang. Pada bangun 4 layang-layang subjek NO mengungkapkan bahwa bangun 4 mempunyai 2 sisi yang sama panjang dimana sisi yang ditunjukkan adalah sisi yang berdekatan bukan sisi yang berhadapan. Subjek NO mencoba mengelompokkan kembali bangun tersebut dan mampu menyebutkan pengelompokkan dengan dasar sisi sejajar dan mampu menyebutkan sisi sejajar yang dmiliki setiap bangun datar. Kesimpulan dari jawaban soal tes dan wawancara, subjek FP paham secara visual tetapi kurang teliti mengenai sifat-sifat yang dimiliki setiap bangun datar segiempat secara keseluruhan dan sudah bisa menjelaskan dengan benar.

\section{Karakteristik Soal No 4}

Soal pada Gambar 13 dikategorikan sebagai indikator keempat pada aspek keterampilan visual materi pokok segiempat. Dalam menjawab soal, subjek harus paham soal dan mampu melihat informasi-informasi yang diketahui secara visual, mengetahui nama-nama kumpulan bangun datar jajargenjang yang terdapat pada soal. Setelah mampu melihat informasi-informasi mengenai bangun datar yang terdapat pada soal tersebut, subjek dapat mengidentifikasi sifat-sifat yang dimiliki oleh semua kumpulan bangun jajargenjang pada tabel yang terdiri dari 16 sifat bangun datar. 


\section{Deskripsi Keterampilan Visual Subjek Pada Soal No 4}

\section{Subjek FP}

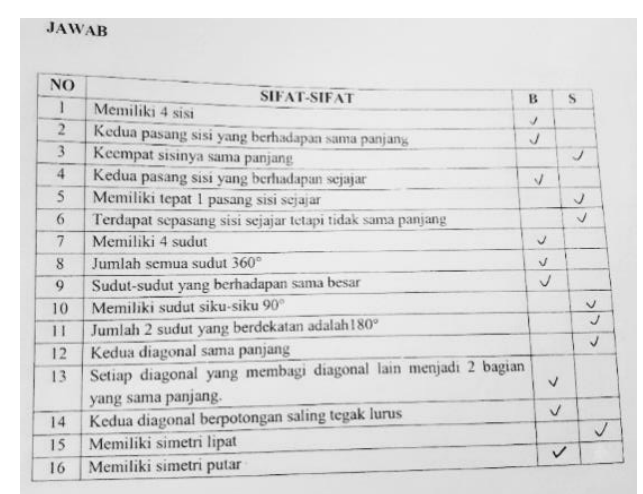

Gambar 10. Jawaban Subjek FP Soal Nomor 4

Berdasarkan hasil jawaban soal tes dan wawancara pada indikator mengamati informasi lanjut berdasarkan pengamatan visual, subjek FP mampu memahami dari soal nomor 4 dan subjek FP dapat menyebutkan jika gambar 4 kumpulan bangun datar jajargenjang teridiri persegi panjang, belah ketupat, jajargenjang sendiri dan persegi. Subjek FP memberi tanda $(\sqrt{ })$ pada kolom $\mathbf{B}=\mathbf{8}$ dan $\mathbf{S}=\mathbf{8}$ dari total 16 sifat bangun datar yang tersedia pada tabel. Dua sifat yaitu pada bagian nomor 11 dan 14 jawaban subjek FP salah, ketika diwawancara pada bagian nomor 11 subjek FP mengungkapkan untuk persegi panjang dan persegi benar apabila jumlah 2 sudut yang berdekatan $180^{\circ}$ karena semua sudutnya adalah sikusiku, tetapi pada belah ketupat dan jajargenjang jumlah 2 sudut yang berdekatan belum tentu $180^{\circ}$ karena terdapat sudut tumpul dan sudut lancipnya. Pada bagian nomor 14 subjek FP mengungkapkan bahwa tegak lurus itu adalah 2 garis diagonal yang saling berpotongan saja sehingga semua bangun kedua digonalnya dikatakan saling berpotongan. Untuk bagian sifat-sifat yang lain subjek FP mampu menjelaskan dan menunjukkan setiap sifat-sifat yang dimiliki oleh semua gambar kumpulan bangun jajargenjang. Kesimpulan dari hasil jawaban soal tes dan wawancara subjek FP sudah paham dalam menentukan dan mengidentifikasi sifat-sifat yang dimiliki oleh semua gambar kumpulan jajargenjang secara keseluruhan, tetapi subjek FP belum mengerti mengenai konsep diagonal berpotongan saling tegak lurus.

\section{Subjek NO}

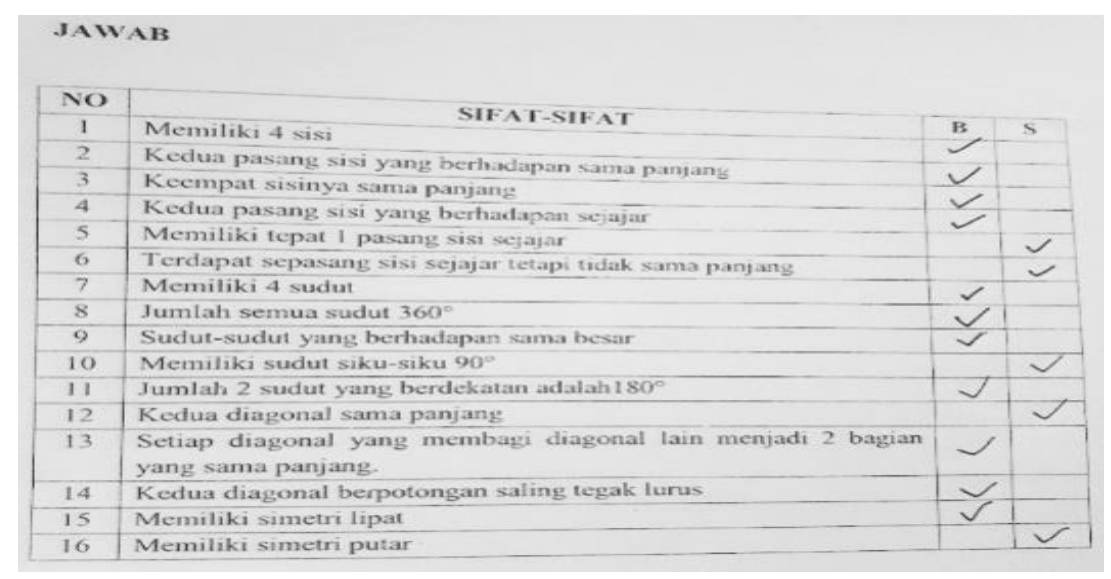

Gambar 11 Jawaban Subjek NO Soal Nomor 4 
Berdasarkan hasil jawaban soal tes dan wawancara pada indikator mengamati informasi lanjut berdasarkan pengamatan visual, subjek NO mampu memahami soal nomor 4 dan dapat menyebutkan jika gambar 4 kumpulan bangun datar jajajrgenjang teridiri persegi panjang, belah ketupat, jajargenjang sendiri dan persegi. Subjek NO memberi tanda $(\sqrt{ })$ pada kolom $\mathbf{B}=\mathbf{1 0}$ dan $\mathbf{S}=\mathbf{6}$ dari total 16 sifat bangun datar yang tersedia pada tabel. Terdapat empat sifat yaitu pada bagian nomor 3,14,15 dan 16 jawaban subjek NO salah, ketika diwawancara pada bagian nomor 3 subjek NO tahu kesalahannya dimana subjek NO terfokus hanya pada bangun persegi tidak kesemua bangun pada gambar 4. Pada bagian nomor 14 subjek NO mengungkapkan bahwa tegak lurus itu adalah yang saling berpotongan saja sehingga semua bangun kedua digonalnya dikatakan saling berpotongan. Bagian nomor 15 subjek NO mengungkapkan jika simetri lipat adalah yang bisa dilipat walaupun tidak saling berhimpit juga dikatakan dilipat. Bagian nomor 16 subjek NO belum paham apa arti simetri putar ketika diwawancara subjek NO terlihat kebingungan dalam menjawab apa arti simetri putar dan bagaimana posisi bangun berubah ketika diputar. Untuk bagian sifat-sifat yang lain subjek NO mampu menjelaskan dan menunjukkan sifat-sifat yang dimiliki oleh semua gambar kumpulan bangun jajargenjang. Kesimpulan dari hasil jawaban soal tes dan wawancara subjek NO cukup paham dalam menentukan dan mengidentifikasi sifat-sifat yang dimiliki oleh semua gambar kumpulan jajargenjang secara keseluruhan, tetapi subjek NO kurang teliti ketika mengidentifikasi sifat yang dimiliki semua bangun jajargenjang dan belum mengerti mengenai konsep diagonal berpotongan saling tegak lurus, simetri lipat dan simetri putar.

\section{Subjek CN}

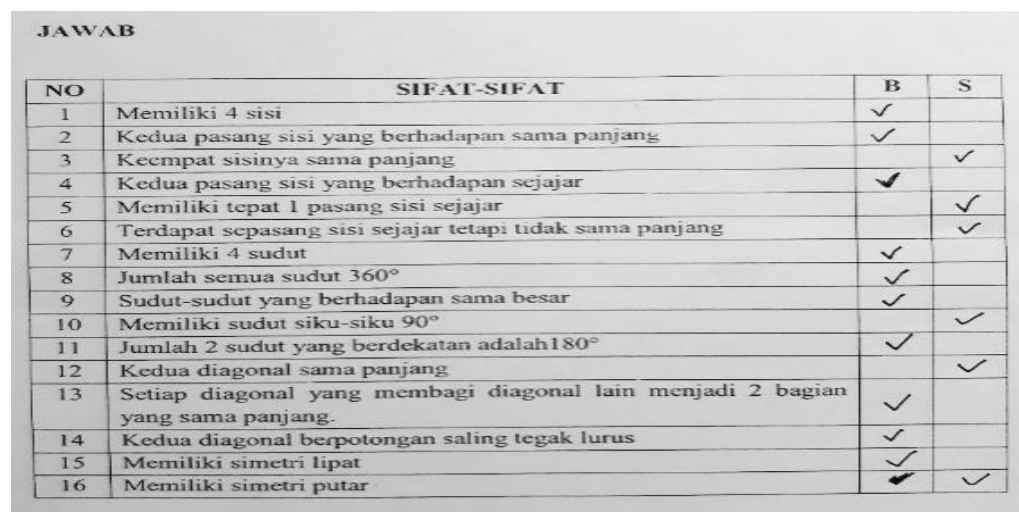

Gambar 12. Jawaban Subjek CN Soal Nomor 4

Berdasarkan hasil jawaban soal tes dan wawancara pada indikator mengamati informasi lanjut berdasarkan pengamatan visual, subjek $\mathrm{CN}$ dapat memahami soal nomor 4 dan mampu menyebutkan jika gambar 4 kumpulan bangun datar jajajrgenjang teridiri persegi panjang, belah ketupat, jajargenjang sendiri dan persegi. Subjek $C N$ memberi tanda $(\sqrt{ })$ pada kolom $\mathbf{B}=\mathbf{1 0}$ dan $\mathbf{S}=\mathbf{6}$ dari total 16 sifat bangun datar yang tersedia pada tabel. Terdapat tiga sifat yaitu pada bagian nomor 14,15 dan 16 jawaban subjek CN salah, ketika diwawancara pada bagian nomor 14 subjek mengungkapkan bahwa tegak lurus itu adalah yang saling berpotongan saja sehingga semua bangun kedua digonalnya dikatakan saling berpotongan. Bagian nomor 15 subjek CN mengungkapkan simetri lipat terbentuk ketika sudut disetiap 
pojok saling berhimpit atau harus pas ketika dilipat, ketika melihat kembali semua bangun datar pada gambar 4 subjek $\mathrm{CN}$ menegtahui kesalahannya dimana jajargenjang tidak memiliki simetri lipat karena ketika dilipat sudut disetiap pojok tidak berhimpit. Pada bagian nomor 16 pada saat wawancara subjek CN ketika menjawab awalnya bingung, subjek CN paham tentang simetri putar dimana ketika diputar nanti harus kembali kebentuk semula, pada saat disuruh menunjukkan banyaknya simetri putar pada semua bangun subjek CN mengungkapkan untuk bangun jajargenjang tidak memiliki simetri putar. Untuk bagian sifat-sifat yang lain subjek CN mampu menjelaskan dan menunjukkan sifat-sifat yang dimiliki oleh semua gambar kumpulan bangun jajargenjang. Kesimpulan dari hasil jawaban soal tes dan wawancara subjek $\mathrm{CN}$ sudah paham dalam menetukan dan mengidentifikasi sifat-sifat yang dimiliki oleh semua gambar kumpulan jajargenjang secara keseluruhan, tetapi subjek CN kurang teliti ketika mengidentifikasi sifat yang dimiliki semua bangun jajargenjang dan belum mengerti mengenai konsep diagonal berpotongan saling tegak lurus.

\section{KESIMPULAN}

Berdasarkan hasil analisis dan pembahasan, bahwa subjek FP, NO dan subjek CN bisa menentukan jenis bangun datar segiempat berdasarkan penampilan, posisi yang berbeda dan sifat-sifat yang dimiliki, dalam menjelaskan sifat-sifat bangun segiempat berdasarkan gambar dapat menjelaskan secara spesifik hanya kurang teliti ketika menjawab yang meliputi banyaknya sisi, ukuran sisi, ukuran sudut, kesejajaran sisi dan ketiga subjek juga belum mengerti mengenai konsep diagonal berpotongan tegak lurus. Secara keseluruhan dapat disimpulkan ketiga subjek mencapai setiap indikator soal keterampilan visual geometri materi segiempat. Sehingga dapat dikatakan subjek FP, NO dan CN yang sama-sama memiliki level berpikir analisis van Hiele maka juga akan memiliki kesamaan dalam menyelesaikan soal.

Berdasarkan kesimpulan hasil penelitian di atas, peneliti memberikan saran kepada guru yaitu agar lebih memperhatikan pemahaman konsep setiap siswa pada materi bangun datar segiempat serta perlu ditekankan kembali dalam menjelaskan dan menujukkan sifat-sifat dari setiap bangun yang telah diamati secara visual. Selain itu, hasil penelitian ini diharapkan dapat menjadi sumber informasi bagi peneliti lain dalam mengembangkan atau meneliti keterampilan dasar geometri yang lain atau menggunakan materi yang lain atau meneliti keterampilan dasar visual untuk level berpikir van hiele yang lain .

\section{DAFTAR PUSTAKA}

Abdussakir. 2010. Pembelajaran Geometri Sesuai Teori Van Hiele. Jurnal Kependidikan dan Keagamaan Volume 7 No 2. Fakultas Tarbiyah UIN Maliki Malang.

Aditya, Lisa (2016). Level Berpikir Geometri Menurut Teori Van Hiele Berdasarkan Kemampuan Geometri dan Perbedaan Gender Siswa Kelas VII SMPN 8 Pare-Pare. Jurnal Al-Khawarizmi Volume 4 No 2. IAIN Palopo. 
Analisis Keterampilan Dasar Visual Geometri Siswa SMP Ditinjau Berdasarkan Level Berpikir Analisis Van Hiele, Dewi

Budiarto, MT \& Sofyana, A. (2011). Profil Keterampilan Geometri Siswa SMP dalam Memecahkan Masalah Geometri Berdasarkan Level Perkembangan Berpikir van Hiele. Surabaya: Pusat Penelitian IKIP Surabaya.

Mufarrohah, Holifatul (2015). Analisis Keterampilan Geometri Siswa dalam Menyelesaikan Soal Geometri Pokok Bahasan Segiempat Pada Siswa Kelas IX A SMP Negeri 1 Cermee Bondowoso. Pusat Penilaian Pendidikan Kementerian Pendidikan Dan Kebudayaan. 2018. Penguasaan Materi Ujian Nasional Tingkat SMP Kota Salatiga. Diakses tanggal 25 Februari 2019 dari https://hasilun.puspendik.kemdikbud.go.id

Republik Indonesia. 2017. Model Silabus Pelajaran Sekolah Menengah Pertama / Madrasah Tsanawiyah (SMP/MTs). Jakarta:Depdiknas.

Republik Indonesia. 2016. Permendikbud No. 24 Lampiran 15 Tahun 2016. Tentang Kompetensi Inti Kompetensi Dasar Matematika SMP/MTs. Jakarta:Depdiknas

Risnawati. (2013). Keterampilan Belajar Matematika. Yogyakarta: Aswaja Pressindo

Sholihah, Zainatu S. (2017). Analisis Kesulitan Siswa Dalam Proses Pemecahan Masalah Geometri Berdasarkan Tahapan Berpikir Van Hiele. Jurnal Mosharafa Volume 6 No 2. STKIP Garut.

Sugiyono. (2012). Metode Penelitian Kuantitatif, Kualitatif, dan R\&D.Bandung: Alfabeta. Sugiyono. (2015). Metode Penelitian Kuantitatif, Kualitatif, dan R\&D.Bandung: Alfabeta.

Van De Walle. 2013. Elementary and Middle School Mathematics Teaching Developmentally 8th Editions. New Jersey : Pearson. 